Vol. 1, No. 1 June 2020: p. 43-59. DOI: 10.18326/islah.vli1.43-59

Website: https://e-journal.iainsalatiga.ac.id/index.php/islah

\title{
Hamzah Fansuri: Mystical Quest Of A Controversial Sacred Bird From Nusantara
}

\author{
Ach. Fatayillah Mursyidi \\ Centre for Religious and Cross-cultural Studies (CRCS), Graduate School, UGM \\ ach.fatayillahmail.ugm.ac.id
}

\begin{abstract}
Sufism is a central element in the history of Islamic tradition. Nevertheless, its theological standpoint elaborating inward dimension of religiosity and preferring ascetic way of life has been often a subject of critics particularly from those sharia-oriented clerics. One of their influential figures from Nusantara archipelago is Hamzah Fansuri, a birthplace-disputed controversial mystic who is severely criticized by the opponent of his age, Nuruddin arRaniri. A number of his works were thereupon exterminated for being accused of revealing a deviant aspect of Islam due to in part the rather political than theological quarrel. Instead of aimed to defend his mystical theology, this paper attempts to clarify stern misunderstood on his teachings by distinguishing him with a very well-known Islamic mystic, Ibn Arabi to whom he is often associated, and his alike through categorization on mystical experiences provided by Schimmel (2011). His metaphorical use of sacred bird and some of his other incredible but limited works remain intact after the decimation will also be explored to show his theological position among other Sufis. In conclusion, I argued that neither he excludes personal element of humanity nor he disregard the role of sharia in formulating the ways to reach the mystical union.
\end{abstract}

Keywords: Sufism, Hamzah Fansuri, theological (political) dispute, sharia, sacred bird

\begin{abstract}
Sufisme adalah elemen sentral dalam sejarah tradisi Islam. Namun demikian, sudut pandang teologisnya yang menguraikan dimensi religiusitas ke dalam dan lebih memilih cara hidup asketik telah sering menjadi subjek kritik terutama dari para ulama yang berorientasi syariah. Salah satu tokoh berpengaruh mereka dari kepulauan Nusantara adalah Hamzah Fansuri, seorang mistikus kontroversial yang diperdebatkan tempat kelahiran yang sangat dikritik oleh lawan seusianya, Nuruddin ar-Raniri. Sejumlah karya-karyanya kemudian dimusnahkan karena dituduh mengungkap aspek menyimpang dari Islam karena sebagian dari pertengkaran yang agak politis daripada teologis. Alih-alih bertujuan untuk mempertahankan teologi mistiknya, makalah ini berupaya untuk memperjelas kesalahpahaman yang kuat pada ajarannya dengan membedakan. dia dengan mistik Islam yang sangat terkenal, Ibn Arabi kepada siapa dia sering dikaitkan, dan sama-sama melalui kategorisasi pada pengalaman mistik yang disediakan oleh Schimmel (2011). Penggunaan metaforisnya tentang burung suci dan beberapa karya luar biasa lainnya namun terbatas tetap utuh setelah penipisan juga akan dieksplorasi untuk menunjukkan posisi teologisnya di antara para Sufi lainnya. Sebagai kesimpulan, saya berpendapat bahwa dia tidak mengecualikan unsur pribadi kemanusiaan atau dia mengabaikan peran syariah dalam merumuskan cara-cara untuk mencapai persatuan mistis.
\end{abstract}

Kata Kunci: Sufisme, Hamzah Fansuri, pertengkaran teologis (politis), syariah, burung suci 


\section{INTRODUCTION}

Sufism has been a central element in the history of Islamic tradition. Despite the fierce debate on its theological legitimacy, the thoughtful influence it generated has attracted many scholars and theologians, Muslim and non-Muslim, to discuss the paradigm. Some of them are disposed to consider it as a mystical aspect of Islamic civilization. This is not wrong but not really true as well as given the dynamic of definition on the word 'mysticism'. This is true since Sufism was defined by Junayd in the letters of al-Qushayri ${ }^{1}$ (1964) as a mystical state achieved only by "the security of the heart and the generosity of the soul". Nevertheless, this is also wrong by suggesting the variety of Sufism some of which do not encourage its performers to renounce worldly affairs.

In academic literature, Annemarie Schimmel ${ }^{2}$ attempted to formulate those varieties into two type of mystical experience; Mysticism of Infinity and Mysticism of Personality. In the former type, God is conceived as the Being beyond everything. He is totally infinite so that he cannot be described by any finite categorical subject. In Sufis literatures, He is often symbolized as 'the boundless ocean in which the individual self vanishes like a drop, or as the desert, which shows itself in ever new sand dunes that hide its depths, or as the water out of which the world is crystallized like ice'. According to Schimmel, Ibn 'Arabi School is one of those who close to this type. The second type is less complicated and closer to earthly understanding. It perceived the relation between human being and God as that of creature and Creator, of a slave in the presence of his Lord, or at most, of a lover yearning for his Beloved. This is a purportedly trait of earlier Sufism.

By applying the categorization above, Hamzah Fansuri may be included in the second type of mysticisms. It is evidenced by a well-known gnostic Sufi, Fakhruddin 'Iraqi, by whom along with other Sufis Fansuri has been influenced. Unlike Ibn 'Arabi, 'Iraqi fused the Sufis mystical teaching with Ahmad al-Ghazali's, a younger sibling of Imam al-Ghazali, about Love ('isyq) ' $^{3}$ By combining both, what did he mean by Love is neither a worldly immanent love nor a heavenly untouched one but a coalesced amalgamation of both

1 al-Qushayri, Abu al-Qasim. Ar-rasa'il al-Qushayriyya. Edited and translated by F. M. Hasan. Karachi. (1964).

${ }^{2}$ Annemarie Schimmel, Mystical Dimensions of Islam. Chapel Hill: The University of North Carolina Press. 1975. P. 5.

${ }^{3}$ Abdul Hadi. W.M.). Hamzah Fansuri: Risalah Tasawuf dan Puisi-puisinya. Bandung: Penerbit Mizan. (1995.p. 22) 
dimensions; that is an appearance of God through His logos (knowledge) and attributes. This is one of his teaching later identically appeared in Fansuri's works.

Fansuri is among, or probably the most, prominent Sufis in Nusantara. Interestingly, no one knows when and where exactly he was born and died for there is no historical record on that. As far as it refers to his poetry, there will always be a dispute on whether his was born in Shahr Nawi, a Siamese town, or Fansuri, an Arabian word for Barus, a town situated on the western coast of North Sumatra, somewhere in between Singkil and Sibolga. It is said that;

Hamzah nin asalnya Fansuri

(Hamzah is originally of Fansur)

Mendapat wujud di tanah Shahr Nawi

(He acquired his existence in the land of Shahr Nawi)

Notwithstanding the obscurity of his birthplace, it does no longer matter either for himself or this paper. As a great Sufis, the place where he was born is far less important than the place where he could eventually find God. Likewise for this paper as the concern will be more at his spiritual journey rather than his personal biography. What did he achieve? How did he articulate his desire of God? What are the paths he suggested to pass through in order to reach a unity with God? Does that achievement presuppose a disregard of sharia both in its esoteric meaning (such as committing virtue and refrain from perpetrating felony) and exoteric one (such as performing Islamic rituals)? Those are among the questions that will be addressed through this discussion.

Unfortunately, not much of his works is still intact until today and come down to us. It is believed that the political quarrel at his time has led to the decimation of some of his remarkable works for they were accused as revealing a deviant aspect of Islam. In fact, like what has been experienced by other Sufis in their encounter with political authority, his teaching was presumably challenging their authorities since it was carrying an egalitarian aspect of Islamic values. This particular aspect contains a spiritual conviction on the image of God in every being that positions them in equal degree because of which social hierarchy has no space.

As the result, there are only thirty six (36) manuscripts produced by his hand comprising of 3 letters of tasawwuf and 33 bundled poems (each bundle consist of 13, 15, or 19 palindromes). The first three letters are Syarah Al-'Asyiqin (The Beverage of the Lovers), Asrar Al-'Arifin (The Secrets of the Gnostics), and Al-Muntahi (The Adept). The first and 
the second of those were edited by Doorenbos and re-edited by al-Attas (1970: 297-328, 416447, 233-296, 354-415). The first letter discusses four teachings; the four stages of the mystic path and how to act at each of these, the doctrine of emanation, God's attributes, and Love and Thankfulness. The second is a running commentary on a didactic poem that basically deal with the relationship of man and God. The third letter, edited also by al-Attas (1970: 329-353, 448-472), is a treatise of a peculiar composition accompanied with a hundred quotations from Qur'an, Hadits (the Tradition of Muhammad), Arabic and Persian poetries. The second manuscript was initially kept in the museum of Jakarta and only later on moved to the National Library of Jakarta ${ }^{4}$.

Those incredible works will be used as the main sources of this paper to which the arguments will be referred. By examining those and later scholarly comments on them, the aforementioned questions are going to be answered, hopefully. The discussion will be started with introducing the intellectual background of the figure in point followed by the usage of metaphorical bird in the second section and the ways he proposed through which the mystical union can be accomplished in the third section until finally it will be ended by seeing what those discussions actually prove through a brief conclusion.

\section{DISCUSSION}

\section{Wujudiyah: An Introduction of His Intellectual Background}

In addition to the political matter, theological contestation was also one of the reasons behind the continuously inconvenient treatment on the poet, Fansuri. His particular teaching on wujudiyah was suspected of being derived from the theory of seven dignities. In fact, this suspicion was repelled by the historical fact that the theory was only developed in Nusantara since the beginning of 17 th century by his own disciple, Syamsuddin As-Sumatrani. Though the theory is one of wujudiyah thoughts but it was much swerved from its original essence into which the influence of Indian practices were inserted such as yoga in a zikir, a teaching that even criticized by Fansuri himself. However, that is no wonder by considering that the teaching, adapted from Ibn 'Arabi, firstly developed by Mohammad Fadlullah Al-Burhanpuri from India ${ }^{5}$.

4 Abdul Hadi W.M. Hamzah Fansuri: Risalah Tasawuf dan Puisi-puisinya. Bandung: Penerbit Mizan. (1995). P.19-20.

${ }^{5}$ Abdul Hadi. P. 20. 
As alluded earlier that, rather than immediately Ibn 'Arabi, Fansuri's works and teachings were colored by 'Iraqi's ideas, particularly his idea of Love ('isyq). Accordingly, all God's attributes, which are basically a Love, have been perfectly subsumed in a very common Islamic dictum, Bismi Allah al-Rahman al-Rahim (In the name of God, the Most Gracious, the Most Merciful). In that sentence, there two types of God's Love; Rahman and Rahim. They are derived from a similar root, rahm (blessing). The first is an essential element of God's blessing (dzatiyah) while the second is its obligatory (wujub). It is essential because the first is applying to all of His creatures. All beings are endowed by His Rahman. Meanwhile, the second is obligatory for it should be granted only for those people who love Him with sincerity, those who carry His orders and avoid everything prohibited by Him, and those who strive for His Love. Those two notions can be found also in the following Fansuri's poems:

Tuhan kita yang bernama qadim

(Our Lord, called the Eternal)

Pada sekalian makhluq terlalu karim

(Is most bountiful to all creatures)

Tandanya qadir lagi hakim

(Indicative of both His omnipotence and His wisdom)

Menjadikan 'alam dari al-Rahman dan al-Rahim

(Is that out of mercy and compassion He created the world)

Rahman itulah yang bernama sifat

(This mercifulness is called an attribute)

Tiada bercerai dengan kunci Dzat

(Not distinct from His very Essence)

Di sana perhimpunan sekalian ibarat

(It is the rallying-point of all specifications)

Itulah hakikat yang bernama ma'lumat

(It is what the intelligibles essentially are)

Rahman itulah yang bernama Wujud

(The Merciful is called Being)

Keadaan Tuhan yang sedia ma'bud

(The Lord's Being worshipped through all ages)

Kenyataan Islam, Nasrani dan Yahud

(Islam, Christianity and Judaism)

Dari Rahman itulah sekalian maujud

(Came into being because of that mercifulness)

The second strophe speaks about the ubiquity of Rahman. Without this notion, it is unlikely for everything to reach their beings and thereupon His Rahman is the essence of every being. According to Ibn 'Arabi, before the process of creation was started, God 
contemplated and discerned into Himself in His Aloneness and $\mathrm{He}$ saw His infinite Knowledge still as hidden treasury (kanz makhfi). Triggered by His Love, He wants to be recognized for which He created and then well recognized. Therefore, His creatures are intelligibles (ma'lumat) from His Knowledge through which He was eventually recognized. In the last strophe, he said that rahm (Rahman and Rahim) is a synonym of Love, and Love is synonymous of Being. It is also noteworthy that he conceived Love inclusively by including not only Islam but other two Abrahamic religions as well, one of controversial Sufis teaching that, in some cases, brings them to persecution.

Those terminologies are only few of many other Qur'anic holly terms interspersing throughout his poems some of which are cited completely in a sentence. Those are in favor of his wujudiyah teaching. He addressed the omnipresence of God immediately in the other strophes by quoting some verses from Al-Qur'an. Kulla yawm huwa fii Sya'n is a 29th verse of Ar-Rahman that means "Every day He is (engaged) in some affairs". By quoting this verse, we can understand that the author perceived that the God's Essence is never separated from the circulation of universe and the creatures. The word 'haqiq' is coming from Surah $A l-A$ 'raf verse 105 . In this verse there is a story where Moses was declaring himself as a Messenger of God and asserting that he says nothing unless the truth (haqiq) about God. Since God is the truth then he deserves of worshipping.

Another verse is taken from Surah Al-Baqarah verse 115 that says "Ayna-ma tuwallu fa tsamma wajh Allah (So wherever you turn (yourselves or your faces) there is the face of Allah). Actually, this particular verse has been always quoted by other sufis to theologically justify their specific teaching on the presence and closeness of God to His creatures. They usually translate the word 'wajh' as an Essence, that is God's attributes. Here are the poems:

Ma'bud itulah yang terlalu bayan (The Worshipped One is exceedingly manifest)

Pada kedua alam kull yawm huwa fii sya'n

(In both worlds each day He is in something engaged)

Ayat ini daripada Surah Al-Rahman

(This verse is from the chapter 'The Merciful')

Sekalian alam di sana hairan

(The entire universe marvels at it)

Mu'bud itulah yang bernama haqiq

(The Worshipped One is the Real One)

Sekalian alam di dalamnya ghariq

(The entire universe is immersed in Him)

Olehnya itu sekalian fariq 
(Therefore, none of the parties)

Pada kunhi-Nya tiada beroleh tariq

(Has grasped His actual being)

Haqiqat itu terlalu 'iyan

(This Reality is most obvious)

Pada rupa kita sekalian insan

(To our kind, the human race)

Ayna-ma tuwallu suatu burhan

(As evidenced by the words 'Wherever ye turn)

Fa tsamma wajhu Allah pada sekalian maqan

(There is God's countenance' everywhere)

In regard to the word 'rahman', Fansuri was also known to have been influenced by Abd al-Karim al-Jili, a descendant of the great sufi saint, Abdul Qadir al-Jailani, who wrote Universal Man. This book is basically an explanation of Ibn Arabi's teachings on the structure of reality and human perfection since the author himself was the one of the greatest and foremost exponents of the work of Ibn Arabi. According to this sufi, Rahman is consisting of seven God's main Attributes; Hayy (Life), 'Ilm (knowledge), Iradat (Will), Qudrat (Power), Sami' (Hearing), Basir (seeing), and Kalam (Speak). Interestingly, in the bundle of his poems Fansuri was also saying the same words:

Aho segala kita yang menyembah 'kan nama

(Oh all of us who worship the Name)

Yogya diketahui Yang Pertama

(One should know what comes first)

Karena Tuhan kita yang Sedia Lama

(For our Lord is the Eternal One)

Dengan ketujuh Sifat bersama-sama

(Inclusive of His seven attributes)

Tuhan kita itu yang Empunya Dzat

(Among the attributes of our Lord, the possessor of Essence)

Awwalnya Hayy pertama bilang Sifat

(That of living ranks first)

Keduanya 'Ilmu dan Rupa Ma'lumat

(His second attribute is that He knows all objects of knowledge as they are)

Ketiga Murid 'kan sekalian Iradat

(The third, that He is willing, (which comprises) all His acts of Will)

Keempat Qadir dengan Qudrat-Nya tamam

(The fourth is that He is almighty)

Kelimanya Sifat bernama Kalam

(The fifth is the attribute of speech)

Keenamnya Sami' dengan Ada-Nya dawam

(The sixth, that of hearing, permanently operative)

Ketujuhnya Basir akan halal dan haram

(The seventh, that He sees what is permitted and what is forbidden) 
Those characters are only eternally attributed to God who is fully conversant of the disposition of the universe $\mathrm{He}$ created. He is alive for maintaining the world in balance. $\mathrm{He}$ knows everything in this planet from which His will and power are derived. He is hearing as well as seeing what is permitted and forbidden for His servants, meaning that no one can escape from His observation. However, this is not to be translated literally for God is understood as closer to us than our own jugular vein. In other word, we are the waves in a fathomless Ocean into which we will finally merge.

\section{The Usage of Metaphoric Sacred Bird}

It is quite common to read mystical literatures in Islamic tradition using a bird to describe their Sufis activity. A bird is always symbolized as a soul who is performing a spiritual journey to find the One he loved. It is telling that the journey should pass over the finite world with all of its seductions to come back again to its original place that is heaven. In fact, not all birds (red: souls) can successfully finish the journey as some of which are trapped in a worldly cage. The cage is an allegoric word of body by which human are often suffered. Therefore, human being is supposed to not being tempted by their physical body and forget their divinely duty to find a God with whom they are expected to be united.

In Islamic tradition in particular, in addition to soul, a bird is also associated with intelligence and love. The first association is represented by a story of the first burial in human history that was committed by Qabil to Habil, two sons of Adam. By referring to the narrative story of Al-Qur'an, it is told that Qabil was confused after murdering his brother, Habil. In that panic situation, he saw two ravens fought each other until one of them was died. The murder scratched the ground and buried the body of the dead raven; showing Qabil what have to do with his brother's body. The second association is reflected by the story of Solomon with his hud-hud bird, which is later allegedly identified as a woodpecker. He once sent his bird to fly over other kingdoms including a kingdom led by a woman sun worshipper and tell him what it has seen afterward. After hearing what has been told by the bird, Solomon sent it back to deliver his letter for the queen. Instead of a surrender demand or war declaration, the letter was basically containing a peaceful message.

Nevertheless, the metaphoric usage of bird in mystical tradition is not something new by suggesting that Ibn Arabi, Fariduddin Attar, and other early prominent Sufis have used the metaphorical animal as well at their times. Attar named one of his masterpiece Mantiq 
at-Tayr, which literally means the Conference of the Birds, by referring to the story of Solomon above who, according to Al-Qur'an, is taught the language of the birds. Through this peerless work, he used Solomonic knowledge of bird language to explain the metaphoric meaning of the family of the birds according to whom they are those who are not completely at home in this world but rather who long for their origin in the paradisal abode. To fulfil that unbearable longing, they should carry out a spiritual quest throughout their life for which their wings are supposed to use.

Two centuries earlier, Ibn Sina wrote one of among his less familiar work titled Risalat al-Tayr that means Treatise on the Bird. While Attar deals with the supreme spiritual and mystical experience of Union by going through Ghazalian model of suffering through which the birds are finally able to enter the court of the celestial King, Ibn Sina deals with the intellectual vision that allows such journey possibly completed ${ }^{6}$. This work was later on restated and translated by another influential Sufi, Suhrawardi, into Persian language.

By using the same allegory, Fansuri in Nusantara centuries after their time re-adopted the usage of birds in his works. It is known that he often mentions a fowl throughout his poems and give one of his work a title Syair Unggas (a poem of fowl). However, this is not startling given that he possesses a very poetic skill of wording through which his romantic works were massively born. One group of his poems is even titled with "The Poem of LightYellow Bird". Following Drewes and Brakel arrangement of the whole series of his poems ${ }^{7}$, here I provide only one part of the group:

\section{Thayr al- 'uryan unggas sultani}

(The naked bird is a royal bird)

Bangsanya nur al-rahmani

(Springing from the Divine Light)

Tasbihnya Allah subhani

(Its doxology is "God, praise be unto Me")

Gila dan mabuk akan rabbani

(It is infatuated with dominical status)

Unggas itu terlalu pingai

(The bird is bright yellow)

Warnanya terlalu bisai

(Its color is most brilliant)

\footnotetext{
${ }^{6}$ Nasr, Seyyed H. Islamic Art and Spirituality. Albany: State University of New York Press. (1987). $\mathrm{p}, 100$.

${ }^{7}$ Drewes, G.W.J. \& Brakel, L.F. (1986). The Poems of Hamzah Fansuri. Leiden: Foris Publications Holland.p. 36.
} 
Rumahnya tiada berbidai

(Its abode has no shutters)

Duduknya da'im di balik tirai

(It always stays behind a curtain)

Awwalnya bernama ruhi

(It is of spiritual origin)

Millatnya bernama sufi

(Its creed is utterly mystical)

Masyafnya besar bersurat kufi

(Its sacred book is of great extent and in Kufi script)

Tubuhya terlalu suci

(Its body is most sacred)

Arasy Allah akan pangkalannya

(God's throne is its starting-place)

Habib Allah akan taulannya

(God's beloved its companion)

Bait Allah akan sangkarannya

(God's house its cage)

Menghadap Tuhan dengan sopannya

(It respectfully waits upon the Lord)

Sufinya bukannya kain

(Its mysticism is not a matter of garb)

Fi'l-Makkah da'im bermain

(Mecca is its permanent pleasure-ground)

Ilmunya zahir dan batin

(Its knowledge is both exoteric and esoteric)

Menyembah Allah terlalu rajin

(It is wholly taken up by worshipping God)

Kitab Allah dipersandangnya

(It girds itself with the book of God)

Gaib Allah akan tandangnya

(It faces God's mystery)

Alam lahut akan kandangnya

(The divine sphere is its enclosure)

Pada da'irah Hu tempat pandangnya

(Its meditation is focused on the circle of $\mathrm{Hu}$ )

Zikir Allah kiri kanannya

(It is all over mindful of God)

Fikir Allah rupa badannya

(It is devotion incarnate)

Surbat tauhid akan minumannya

(The beverage of unity is its drink)

Daim bertemu dengan Tuhannya

(It is in constant union with its Lord)

Suluhnya terlalu terang

(Its torch is shining brightly)

Harinya tiada berpetang 
(Its day never passes into noon)

Jalannya terlalu tenang

(Its course is most steady)

Barang mendapat dia terlalu menang

(Whosoever achieves it is most victorious)

This is the first part out of four parts of his bird-poems that describes a bird that has accomplished its mystical journey and attained union with its Loved. In that completed circumstance, the only name he remembered and uttered is the name of the One he loved by praising Him endlessly. Like a man loving his beloved spouse, even more than that, he got drunk of a priceless inebriating love by which he aspires nothing unless God. It has been nuts about the Ultimate Being of God.

In this sense, Arabi's and Attar's aroma are felt as he implicitly referred to the naked bird of Mantiq al-Thayr that has shed its feathers as a sign of being free from all earthly amusements; that is a confinement of worldly stage from which Attar's birds are attempting to escape by flying away with their wings. Of seven dangerous valleys conceptualized by Attar, some of them are also cited by Fansuri to accentuate its significance within the birds' journey. The love ( 'isyq), for instance, that is quested (talab) by his birds is an "encountering with God". Nevertheless, those who are still busied with worldly affairs accordingly will never traverse the path of gnostic (ma'rifah) to be in unity (tawhid);

Kerjamu itu hai anak dagang

(Your doings, oh stranger)

Pada ahl al-ma'rifah terlalu malang

(Are unpropitious in the eyes of gnostics)

Markab tauhid yogya kau pasang

(Get ready the vessel of unity)

Di tengah laut yang tiada berkarang

(In order to sail the rockless sea)

The poet also described the beauty of that accomplishment after which the mystic is no longer determined by the clothe, he wears but rather by his esoteric and exoteric knowledge as well as endlessly praying and praising God. Finally, everything is about God; his clothe, place, breath, and vision. In addition, it is interesting also to see how he used the word 'surbat', rather than a wine such early Persian Sufis, to contextualize his works in order to be easily understood by the Malay readers. By considering that, no doubt that his works have reached out all layers of society in all spaces and times. 
That is only one group out of four groups of his bird-poems. The next groups mostly deal with the idea of the bird being absorbed in the divine unity for which four paths are formulated; shari'a, tariqa, haqiqa, and ma'rifa. Those ways will be explored more in the next section.

\section{Ways of Discovering God}

The idea of 'Perfect Being' is another common concept in Sufis tradition. The idea has been always proclaimed by Sufis to encourage their disciples and readers to go through certain paths in order to love and be loved by God. The only religious figure to which this idea is often associated is, of course, the Prophet of Muhammad, for he is believed in Islamic tradition as a sinless person (ma'shum). This sacred position is amplified within the Islamic pretext, it is said that he is even warranted to enter the heaven without trial. Although the idea of 'Perfect Being' is originally coming from Mansur al-Hallaj and Al-Biruni but it was defined explicitly by Ibn 'Arabi in one of his books, Fusus Al-Hikam, by referring to the Prophet:

"Muhammad Wisdom is uniqueness (fardiya) because he is the most perfect existent creature of this human species. For this reason, the command began with him and was sealed with him. He was a Prophet while Adam was between water and clay, and his elemental structure is the Seal of the Prophet."

This concept is also appeared in Fansuri's works along with the strategies to being such Being. The aforementioned verse of Al-Baqarah was also quoted in his other strophe with regard to the way of 'Perfect Man' in discovering his God.

\section{Mahbubmu itu tiada berha'il}

(The way to your Beloved is not blocked)

Pada ayna-ma tuwallu jangan kau ghafil

(Be mindful of the words 'Wherever ye turn)

Fa tsamma wajhu Allah sempurna wasil

(There is God's countenance', (evidence of) complete union)

Inilah jalan orang yang kamil

(Such is the walk of the perfect man)

In this section, I will randomly refer to his pieces to see what are his suggestions to his disciples with regard to the ways before coming to his four pivotal means of being such Perfect Being in union with the Loved. It seems that he is sensitively care of the week people 
for he asked personally his disciple to closer to the poor and marginalized people instead of wealthy as the later might lead you far away from God:

Jikalau bersahabat dengan orang kaya

(If you befriend with the rich)

Akhirnya engkau jadi binasa

(You will finally be devastated)

Aho segala kamu anak alim

(Oh all ye that are of pious family)

Jangan bersahabat dengan yang zalim

(Do not befriend the oppressors)

Karena Rasulullah sempurna hakim

(For God's Messenger, the highest authority)

Melarangkan kita sekalian khadim

(Has forbidden this to us, his servants)

Aho segala kamu yang menjadi faqir

(Oh all ye that have taken the vow of poverty)

Jangan bersahabat dengan raja dan amir

(Do not befriend Princes and Rules)

Karena Rasulullah bashir dan nasir

(For the Messenger of God, bringer of joyful tidings and warnings)

Melarangkan kita saghir dan kabir

(Has forbidden this to both the small and the great among us)

Those poems imply that Fansuri's mysticism is not elitist by which it means that he discourages his disciples to being close to power and wealth. These two categories are of worldly amusements and serious impediments for mystical sojourn. Above all, unlike Attar with his seven valleys, Fansuri mentioned four Islamic ways of achieving God in his poems.

There are two strophes in which he mentions the four ways completely:

\section{Shariat akan tirainya}

(The sacred Law is its curtain)

Tariqat akan bidanya

(The Path is blind)

Haqiqat akan ripainya

(Reality its stake(?))

Ma'rifat yang wasil akan isainya

(Uniting gnosis its content(?))

Jika lelah kau turut shari'atnya

(Once you are following Muhammad's Law)

Mangka kau dapat asal tariqatnya

(You have grasped the principle of his 'Path')

Ingat-ingat akan haqiqatnya

(Be constantly aware of his 'Reality')

Supaya tahu akan ma'rifatnya

(So that you may attain his 'Knowledge') 
Shari'at is basic religious laws in Islamic tradition. They are derived from the two main sources in Islamic precepts; al-Qur'an and Hadits (prophetic tradition) (Renard, 1996: 306). Theologically speaking, those laws are obliged for all Muslim with no regard to the time and place as long as they are capable of performing them. The strong commitment of the poet on shari'at can be seen in how in some places of his poem he urged the readers to perform shalat (daily five-time prayers) and sa'im (fasting) as few of among obligatory rituals. He even also suggested of being pious servant who tirelessly carrying out other optional religious rituals such as reciting the Holy Qur'an.

Those religious services are necessary in terms of finding the haqiqat in order to reach ma'rifa in the very end. The poet emphasized the significance of upholding shari'at in which haqiqat is abiding. Accordingly, those who are neglecting the laws are ignorant heathen. These statements can be traced in following pieces of his poem:

\section{Shari'at itu yogya kau taruh}

(Uphold the Law)

Dalam shari'at haqiqat tiada jauh

(From the Law to deeper knowledge is no far cry)

Shari 'atnya terlalu kamil

(Its way is most perfect)

Barang yang mungkir menjadi jahil

(Anyone scorning it is an ignorant heathen)

Of course, Muslim scholars in an attempt of understanding those laws are differ to each other from which the four prominent schools in Islamic tradition were eventually born. Despite the debate among those schools on the elements of shari'at, they shared one voice of campaigning the obligation shari'at as the pillar of Islam. Furthermore, by invoking this practical idea, Fansuri can somehow avoid the charges of his opponents as he as well as other Sufis is often accused as underestimating the role of shari'at in Islamic precept.

Tariqat is a school or order of Sufis tradition, or specifically a concept for the mystical teaching and spiritual practices of such an order with the aim of seeking what so called Haqiqa, which is best translated as "Ultimate Reality". Every tariqat has a murshid (guide) who plays the role of leader or spiritual director. The members or followers of a tariqa are known as muridin (singular murid), meaning "desirous" or "desiring the knowledge of God and loving God" (also called a Faqir). This path is undoubtedly needed by suggesting that man need a guide or supervisor to find the way of God. Fansuri portrayed the significant role of a murshid by describing consequences of not obeying them such as follows: 


\section{Barangsiapa munkir daripada ustadh}

(All those who deny the Master)

Menjadi kafir, taghau fi 'l-bilad

(Are unbelievers who 'lord it in the country)

Fa-aktharu '1-fasad

(And increase therein corruption')

Seperti kawm Thamud lagi dan 'Ad

(As did the people of Thamud and 'Ad)

The last part of the second couplet is taken from Qur'anic verse of al-Fajr surah that means "transgressing beyond bounds in the lands (in the disobedience of Allah)." This verse, followed by the next couplet meaning "And made therein much mischief," refers to Fir' aun and his followers. The story of the people of Tsamud and 'Ad in other Qur'anic verses is also quoted to delineate the peril of being disobedient to a mystical figure who is sent by God. Likewise, this concept saved Fansuri from being accused as anti-social such as many others Sufis are for defending a teaching that everyone by himself can attain a spiritual enlightenment.

Haqiqa is a difficult concept to translate since it is not a state that we can grasp by merely using our common senses. In his book, Islamic Philosophical Theology (1979), Morewedge defined it as "what is real, genuine, authentic, what is true in and of itself by dint of metaphysical or cosmic status" ${ }^{8}$, which is actually a valid definition but does not explain its role in Sufis conception. In regard to our discussion, Haqiqa may be best defined as the knowledge that comes from communion with God, knowledge gained only after the shari'at and tariqat are undertaken. According to the poet, what sensed in this knowledge is none but drunkenness and sense of union:

\section{Lain daripada mabuk dan ilmu wasil}

(All but drunkenness and sense of union)

Pada ahlu '1-haqiqah sekalian batil

(Is void to the initiated)

In this stage, everything is void but the feeling of love toward the Loved. For those who have achieved this mystical stage, what they need to do is letting themselves pervaded by the Ultimate Reality. Nevertheless, this process should be undertaken with full conscience that they are nothing but One. As such, this is less a stage in itself but best

\footnotetext{
${ }^{8}$ Morewedge, Parviz. Islamic Philosophical Theology. Albany: State University of New York Press. (1979)
} 
regarded as the marker of a higher level of spiritual consciousness, which precedes the next and final stage, ma'rifat.

Ma'rifat, which literally means knowledge, is the term used by Sufi Muslims to describe mystical intuitive knowledge of spiritual truth reached through ecstatic experiences, rather than revealed or rationally acquired. This is the summit of the mystical journey to which all Sufis are leading to wholeheartedly. Fansuri mentioned this term for many times throughout his works. He argued that it is both superior and immense; this is the true knowledge that must be inquired by those who are committing spiritual quest. Along with haqiqat, it is regarded as a meaningful value.

Ma'rifat itu sempurna 'ali

(That 'Knowledge' is superior by far)

Pada sekalian Islam terlalu ghali

(And of immense worth to all Muslims)

Itulah ilmu yogya kau cari

(That is the knowledge after which you should strive)

Supaya jadi engkau ruhani

(So that you become spiritual)

\section{CONCLUSION}

The number of classical Sufis, ranging from Ibn Arabi to Fariduddin Attar, by whom Fansuri has been influenced shows that he is neither a heretical Sufi who syncretizes various values and traditions within a single mystical teaching nor a pantheistic mystic who completely obscures the categorical lines between God and His creations by overlooking the dimension of humanity, such as charged by Nuruddin ar-Raniri who severely criticizes him and his mystical teachings. What ironic is that this charge was followed by obliteration of his works and even his name from the history of Nusantara since Raniri was appointed as royal religious scholar after which it is hard to find the remnant of his works.

In fact, this accusation was undoubtedly incorrect by considering that even Fansuri himself criticized other heretical Sufis who have exercised mystical teaching in astray; those who are suffering and isolating themselves from society and looking for a Divinity in a forest for months. Some strophes of his poems indicate his disavowal of those types of mystical way. Instead, he believed that God could be discovered within ourselves.

By distinguishing him from Ibn 'Arabi through categorization on mystical experiences provided by Schimmel in this discussion, the case seemed to being clearer. As a 
Sufi who exercises the Mysticism of Personality, he does not exclude personal element of humanity. It is strengthened by the fact that he does not disregard the role of syari'at in formulating the ways to reach the mystical union. It is appeared through his poems where he explicitly encourages his disciples and readers to perform what is obliged by Islam and avoid what is prohibited. Understanding his teaching in particular and the complexity of mystical teachings in Islamic tradition in general would be expected to anticipate similar political contestation that carries a negative impact on civilization in the future.

\section{REFERENCES}

al-Qushayri, A. a.-Q. (1964). Ar-rasa'il al-Qushayriyya. Edited and translated by F. M. Hasan. Karachi.

Drewes, G., \& Brakel, L. (1986). The Poems of Hamzah Fansuri. Leiden: Foris Publications Holland.

Hadi, A. W. (1995). Hamzah Fansuri: Risalah Tasawuf dan Puisi-puisinya. Bandung: Penerbit Mizan.

Morewedge, P. (1979). Islamic Philosophical Theology. Albany: State University of New York Press.

Nasr, S. H. (1987). Islamic Art and Spirituality. Albany: State University of New York Press.

Renard, J. (1996). Seven Doors to Islam: Spirituality and the Religious Life of Muslims. California: Regents of the University of California.

Schimmel, A. (1975). Mystical Dimensions of Islam. Chapel Hill: The University of North Carolina Press. 